\title{
太陽集光装置における集光部の熱流束計測 （熱流束計測システムの開発）
}

\section{Heat Flux Measurement of Light Collecting Portion in the Solar Concentrator -Development of Heat Flux Measurement system- \\ ○学 原川 剛志（宮崎大学院） 正 長瀬 慶紀（宮崎大） 正 友松 重樹（宮崎大） 正 河村 隆介（宮崎大） 正 木村 正寿（宮崎大）}

Tsuyoshi HARAKAWA, University of Miyazaki, Nishi-1, Gakuenkibanadai, Miyazaki-shi, Miyazaki Yoshinori NAGASE, University of Miyazaki Shigeki TOMOMATSU, University of Miyazaki Ryusuke KAWAMURA, University of Miyazaki Masatoshi KIMURA, University of Miyazaki

Key Words: Solar Energy, Heat Flux Measurement, Heat Flux Sensor, Gardon Gage, Calibration System,

\section{1. 緒論}

近年，再生可能エネルギーに注目が集まっており，その 中でも鏡を使用して太陽光エネルギーを集光し，熱として 利用する太陽熱エネルギ一利用は, 同じ太陽光エネルギー を利用する太陽光発電と比べ, 一度太陽光エネルギーを熱 に変換することで用途が発電だけに限定されず，多様性か らも期待が高まっている.太陽熱エネルギー利用にあたり， 効率を左右する要素となるのが光エネルギーを熱に変換す るレシーバと呼ばれる受熱部である。レシーバは熱の用途 に応じ，さまざまな形状のものが存在するがレシーバの評 価を行う際，レシーバへどの程度の太陽光エネルギーが入 射しているのかを知る必要がある。

現在，太陽光エネルギーの計測には一般的にガードン式 熱流束計が使用されている。しかし，ガードン熱流束計は 基本的に水泠が必要であり, 熱流束の計測は定常状態であ る必要があるため, 計測に時間を要する.太陽光強度は時々 刻々変化するため, 太陽集光装置に入力されている太陽光 エネルギーを装置稼働中に計測することが必要であるが, ガードン式熱流束計では不可能である.

本研究においては無冷却かつ非定常状態での熱流束計測 が可能な薄膜型熱流束計 ${ }^{1)}$ を用い, 短時間での熱流束計測 が可能な計測システムを開発し，太陽集光装置を模擬した 太陽シミュレータでの熱流束計測結果をガードン式熱流束 計と比校して評価することを目的とする.

\section{2. 計測原理}

$2 \cdot 1$ ガードン式熱流束計 ガードン式熱流束計は円形薄膜 型の計測装置であり, 図 1 に示すヒートシンクに水を流し て冷却することにより，外周部と中心部の熱接点に温度差 を生じさせる.この温度差を 2 組の熱電対で計測すること に上って, 軸対称の熱伝導方程式から導出される式(1)より 熱流束值が算出できる. また, 熱流束の計測は温度変化の ない定常状態で行う必要がある.

$$
q=\frac{4 \delta \lambda}{R^{2}}\left(T_{0}-T_{\mathrm{w}^{\prime}}\right)
$$

ただし, $q$ : 熱流束 $\left[\mathrm{W} / \mathrm{m}^{2}\right], \delta:$ 薄膜の厚さ $[\mathrm{m}], \lambda:$ コン スタンタンの熱伝導率 $[\mathrm{W} /(\mathrm{m} \cdot \mathrm{K})], R$ : ガードン熱流束計 の半径 $0.005 \mathrm{~m}, T_{0}$ : 中心部の温度 $[\mathrm{K}], T_{w}$ : 外周部の温度 $[\mathrm{K}]$ とする。

$2 \cdot 2$ 薄膜型熱流束計 図 2 に薄膜型熱流束計の構造を示寸 薄膜型熱流束計は, 直径 $3.2 \mathrm{~mm}$, 長さ $10 \mathrm{~mm}$ のコンスタン
タン製母材金属において，表面及び表面から $5 \mathrm{~mm}$ の内部 の 2 箇所で熱電対を構成している. 表面は電解銅めっきに より表面接点を形成し, 表面から $5 \mathrm{~mm}$ の内部では点溶接 により内接点を形成している. 薄膜型熱流束計は表面の銅 めっきが $10 \mu \mathrm{m}$ と十分薄く, 断熱されているため半径方向 に熱の逃げがない一次元熱伝導であると仮定し, 非定常の 熱伝導方程式から導出した式 $(2)^{2)}$ より薄膜型熱流束計表面 での熱流束值を算出する.

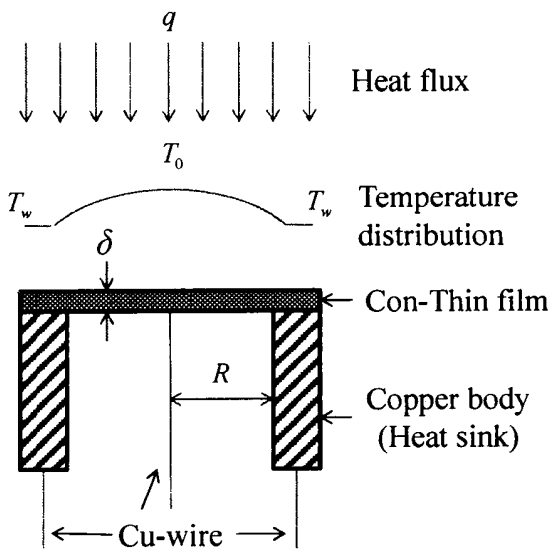

Fig.1 Gardon heat flux gage (cross section view)

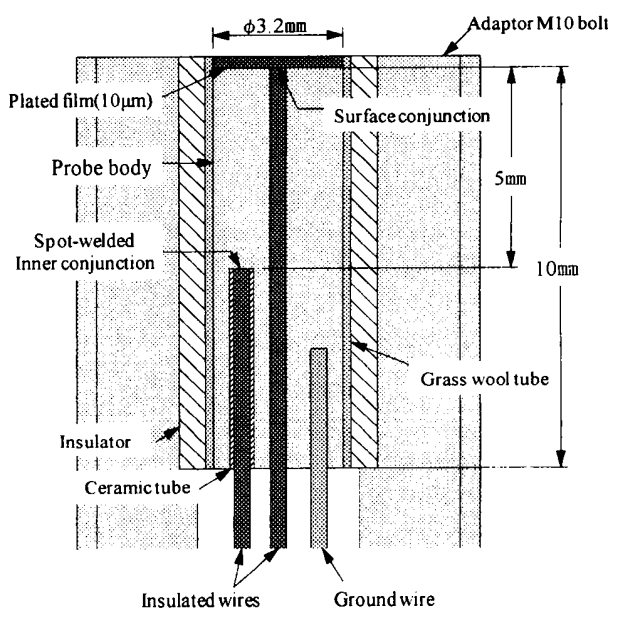

Fig. 2 Heat flux gage (cross section view) 


$$
q_{\left(t_{n} \leq t \leq t_{n-1}\right)}=\frac{2 \lambda}{\sqrt{\pi a}} \sum_{j=0}^{n}\left(k_{(j-1)}-k_{j}\right) \sqrt{\left(t_{(0.1)}-t_{j}\right)}
$$

ここで, $\mathrm{q}$ : 熱流束 $\left[\mathrm{W} / \mathrm{m}^{2}\right], \lambda$ : 熱伝導率 $[\mathrm{W} /(\mathrm{m} \cdot \mathrm{K})], \mathrm{k}$ : 温度の時間勾配 $[\mathrm{K} / \mathrm{s}], \mathrm{a}$ : 熱拡散率 $\left[\mathrm{m}^{2} / \mathrm{s}\right], \mathrm{t}$ : 時間[s]とする。

\section{3. 校正実験}

$3 \cdot 1$ 校正装置 図 3 に示寸校正実験装置を用いて薄膜型熱 流束計の表面薄膜の吸収率を求める。校正装置は，太陽に 対して垂直に置かれた凸レンズにより集光した太陽光を薄 膜型熱流束計に照射するものである.

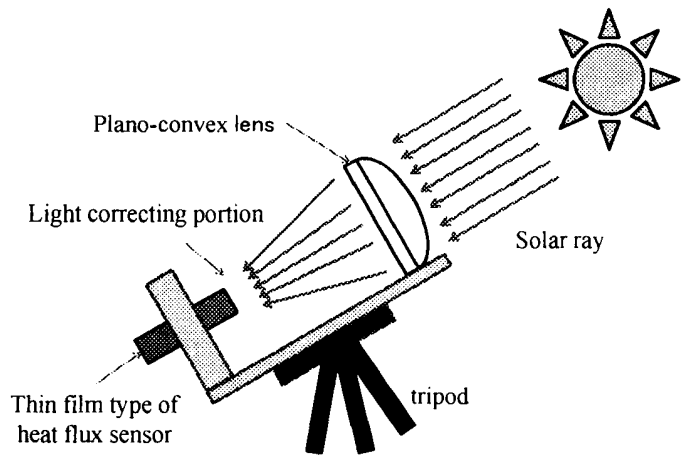

Fig. 3 Calibration system

$3 \cdot 2$ 吸収率算出 校正装置を用いて計測した薄膜型熱流束 計での熱流束值 $q$ 'と直達日射計で計測した熱流束值（直達 日射量） $q$ より, 式(3)から薄膜型熱流束計の吸収率 $\alpha$ を算 出する.

$$
\alpha=\frac{q^{\prime}}{q \times\left(\frac{d_{1}}{d_{2}}\right)^{2} \times \tau}
$$

ただし， $\alpha$ : 熱流束計の吸収率, $\tau$ : レンズの透過率 0.9 , $q$ : 直達日射量 $\left[\mathrm{W} / \mathrm{m}^{2}\right], q^{\prime}:$ 熱流束 $\left[\mathrm{W} / \mathrm{m}^{2}\right], d_{1}$ : レンズの 直径 $70 \mathrm{~mm}, d_{2}$ : 集光部の直径 $[\mathrm{mm}]$ とする.

計測結果から，吸収率 $\alpha$ の值として 0.518 を得た。

\section{4. 太陽シミュレータでの熱流束計測}

$4 \cdot 1$ 熱流束計測システム太陽集光装置に扔いて集光部の 熱流束を計測するシステムを設計・製作した。図 4 に示す ように薄膜型熱流束計が取り付けられたアームは，ステッ ピングモータによって回転し, 薄膜型熱流束計が移動しな がら熱流束分布を計測することのできる構造となっている. なお，集光部の中心位置を確認するため，アームにはフォ トカップラが取り付けられている.

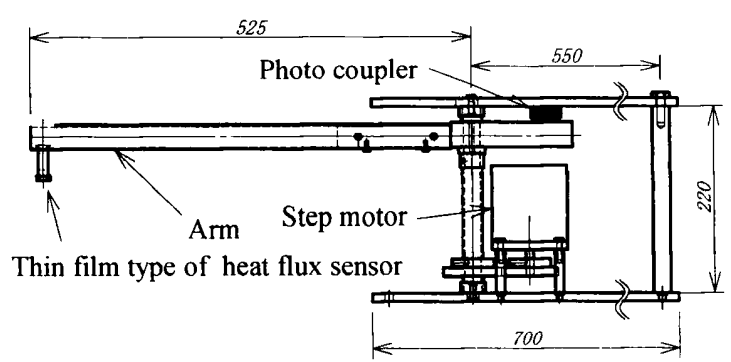

Fig.4 Heat flux measurement system

4·2 太陽シミュレータ 太陽シミュレータは図 5 に示すよ うに，太陽集光装置を模擬するため，光源として太陽光と 同様の分光分布を持つキセノンショートアークランプを使 用している，さらに，棈円鏡を用いてビームダウン式太陽

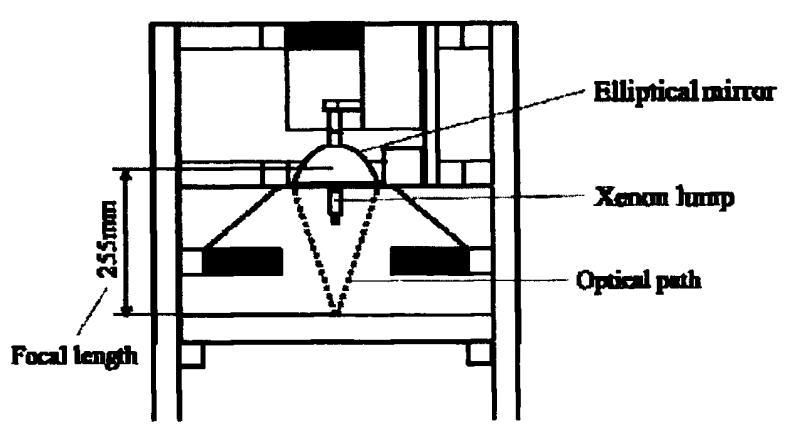

Fig.5 Illustration of solar simulator

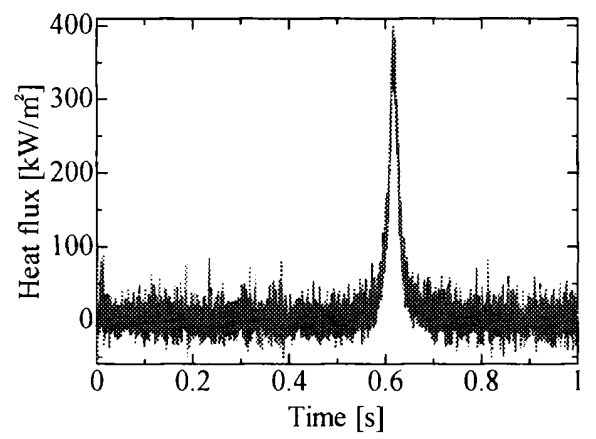

Fig.6 Heat flux measured by thin film type of heat flux sensor

集光装置と同様の集光方法と光路を再現している.なお， 熱流束計測位置は, 集光部でその直径は $30 \mathrm{~mm}$ である。

$4 \cdot 3$ 熱流束計測結果 太陽シミュレータにおいて, 薄膜型 熱流束計およびガードン式熱流束計でそれぞれ熱流束計測 を行った。なお, 薄膜型熱流束計は, 図 4 の装置で移動す るがその周速度は $1 \mathrm{~m} / \mathrm{s}$ で, データのサンプリング間隔は $50 \mu \mathrm{s}$ である。

薄膜型熱流束計による計測結果を図 6 に示す，図 6 にお いて 0.6 秒付近で熱流束が大きく変化しており，ここで薄 膜型熱流束計が太陽シミュレータの集光部を通過している。 図 6 における熱流束の最大值は $400 \mathrm{~kW} / \mathrm{m}^{2}$ である。

一方，ガードン熱流束計は，太陽シミュレータの集光部 に固定して計測した值は $460 〜 470 \mathrm{~kW} / \mathrm{m}^{2}$ であった。

両者の計測結果は，近い值を示したが一致したとは言い 難いので，さらに薄膜型熱流束計計測システムの改良が必 要である。

\section{5. 結論}

太陽集光装置を稼働しながら装置に入力される太陽光エ ネルギーを計測するための熱流束計測システムを開発する ことを目的とし，次の結論を得た。

（1）非定常かつ無冷却で計測できる薄膜型熱流束計による 計測システムを開発した。

（2）薄膜型熱流束計の薄膜の吸収率を求めるための装置を 開発した。

（3）太陽シミュレータによる実験を行い，ガードン式熱流 束計の計測結果と比較したところ, 両者は近い值を示 した.

\section{文 献}

1) 長瀬ほか，機論 B 編 76 巻 765 号, pp.859-864.

2）一色ほか，機論 B 編 39 巻 328 号, pp.3760-3769. 